\title{
Specific ultra-violet absorbance as an indicator of mercury sources in an Adirondack River basin
}

\author{
Douglas A. Burns • George R. Aiken • \\ Paul M. Bradley • Celeste A. Journey • \\ Jakob Schelker
}

Received: 3 February 2012/ Accepted: 27 July 2012/Published online: 9 August 2012

(C) The Author(s) 2012. This article is published with open access at Springerlink.com

\begin{abstract}
The Adirondack region of New York has been identified as a hot spot where high methylmercury concentrations are found in surface waters and biota, yet mercury $(\mathrm{Hg})$ concentrations vary widely in this region. We collected stream and groundwater samples for $\mathrm{Hg}$ and organic carbon analyses across the upper Hudson River, a $493 \mathrm{~km}^{2}$ basin in the central Adirondacks to evaluate and model the sources of variation in filtered total $\mathrm{Hg}$ (FTHg) concentrations. Variability in FTHg concentrations during the growing seasons (May-Oct) of 2007-2009 in Fishing Brook, a 66-km² sub-basin, was better explained by specific ultra-violet absorbance at $254 \mathrm{~nm}\left(\mathrm{SUVA}_{254}\right)$, a measure of organic carbon aromaticity, than by dissolved organic carbon (DOC) concentrations, a commonly used $\mathrm{Hg}$
\end{abstract}

Electronic supplementary material The online version of this article (doi:10.1007/s10533-012-9773-5) contains supplementary material, which is available to authorized users.

D. A. Burns ( $\square)$

U.S. Geological Survey, 425 Jordan Rd., Troy, NY 12180, USA

e-mail: daburns@usgs.gov

G. R. Aiken

U.S. Geological Survey, Boulder, CO, USA

P. M. Bradley · C. A. Journey

U.S. Geological Survey, Columbia, SC, USA

J. Schelker

Swedish University of Agricultural Sciences, Umeå, Sweden indicator. SUVA 254 was a stronger predictor of FTHg concentrations during the growing season than during the dormant season. Multiple linear regression models that included $\mathrm{SUVA}_{254}$ values and DOC concentrations could explain $75 \%$ of the variation in FTHg concentrations on an annual basis and $84 \%$ during the growing season. A multiple linear regression landscape modeling approach applied to 27 synoptic sites across the upper Hudson basin found that higher SUVA $_{254}$ values are associated with gentler slopes, and greater riparian area, and lower $\mathrm{SUVA}_{254}$ values are associated with an increasing influence of open water. We hypothesize that the strong $\mathrm{Hg}-\mathrm{SUVA}_{254}$ relation in this basin reflects distinct patterns of FTHg and SUVA $_{254}$ that are characteristic of source areas that control the mobilization of $\mathrm{Hg}$ to surface waters, and that the seasonal influence of these source areas varies in this heterogeneous basin landscape.

Keywords Mercury - Dissolved organic carbon · Aromatic · SUVA · Adirondack

\section{Introduction}

Organic matter regulates mercury $(\mathrm{Hg})$ cycling in the environment through numerous mechanisms including: ligand binding, effects on dissolution and precipitation, by serving as a microbial substrate, through its central role in redox processes, and as an indicator of hydrologic conditions (Gerbig et al. 2012). The strong 
association of $\mathrm{Hg}$ and organic matter in surface waters has long been recognized (Lindberg and Harriss 1974; Mierle and Ingram 1991), and numerous studies of $\mathrm{Hg}$ in streams and lakes of mid- and northern latitudes of the northern hemisphere have generally shown strong correlations between dissolved $\mathrm{Hg}$ concentrations and dissolved organic carbon (DOC) concentrations, and between particulate $\mathrm{Hg}$ concentrations and particulate organic carbon concentrations (POC) (Grigal 2002; Yin and Balogh 2002; Dennis et al. 2005; Brigham et al. 2009; Riscassi and Scanlon 2011). The association of $\mathrm{Hg}$ with organic matter is sufficiently strong in many surface waters, that measures such as DOC or absorbance at $254 \mathrm{~nm}\left(\mathrm{UV}_{254}\right)$ have been suggested as surrogates for $\mathrm{Hg}$ concentrations, because $\mathrm{Hg}$ analyses are expensive and may be unstable in automated water samplers (Dittman et al. 2009).

Interactions between $\mathrm{Hg}$ and organic matter are numerous and diverse, reflecting the complexity of natural organic matter (Ravichandran 2004; Gerbig et al. 2012). Strong binding of $\mathrm{Hg}$ by sulfur-bearing thiol groups has been shown, and is believed to be a strong driver of $\mathrm{Hg}$ association with dissolved organic matter (DOM) (Benoit et al. 2001; Skyllberg 2008). $\mathrm{Hg}$ may also be bound to organic matter as $\mathrm{HgS}$ nanoparticles that pass through $0.45 \mu \mathrm{m}$ pore size filters, but this form may not be common in surface waters unimpacted by mining activities (Gerbig et al. 2011).

In natural waters, measures that reflect in part, the relative aromaticity of DOM such as the hydrophobic acid (HPOA) concentration or $\mathrm{UV}_{254}$, are often more strongly related to dissolved $\mathrm{Hg}$ than a general measure such as DOC or TOC (Shanley et al. 2008; Dittman et al. 2010; Riscassi and Scanlon 2011). Among several possible reasons for this association is that most reduced sulfur (and therefore, most of the strong $\mathrm{Hg}$ binding sites) is typically found within the HPOA fraction of DOM (Ravichandran 2004), which is more aromatic than the non-HPOA fraction. Additionally, the more aromatic fraction of organic matter may better stabilize $\mathrm{Hg}-\mathrm{S}$ nanoparticles (Ravichandran et al. 1999; Gerbig et al. 2011). Thus, the association of $\mathrm{Hg}$ with the aromatic fraction of organic matter may be rooted in the complex chemistry of $\mathrm{Hg}$ interactions with natural organic matter. In addition to geochemistry-based reasons why $\mathrm{Hg}$ is more strongly associated with aromatic organic matter, this association may also originate through mobilization to surface waters and mixing of $\mathrm{Hg}$ and DOM from principal runoff source areas such as humic-rich shallow soils (Dittman et al. 2010) as well as riparian wetland soils ( $⿱$ gren et al. 2008; Mierle and Ingram 1991), two locations where preferential storage of $\mathrm{Hg}$ has been identified (Grigal 2003). In summary, $\mathrm{Hg}_{-}$ DOM chemistry, storage, and hydrology are interrelated in complex ways that are the subject of ongoing research; thus, determining the primacy of any single explanation for an association that is evident at the basin scale may be difficult.

Although dissolved $\mathrm{Hg}$ and DOC concentrations are often strongly correlated in many surface waters with $r^{2}$ values of 0.7-0.9 (Grigal 2002; Shanley et al. 2008; Dittman et al. 2010; Riscassi and Scanlon 2011), not all waters show such strong a strong association. For example, $\mathrm{Hg}$ and DOC concentrations are weakly related in the Everglades where a diversity of organic matter sources and complex biogeochemical processes are observed (Aiken et al. 2011). Similarly, in surface waters strongly influenced by urban land use, diverse sources of $\mathrm{Hg}$ and DOC such as waste water treatment facilities often preclude a simple linear relation between dissolved $\mathrm{Hg}$ and DOC concentrations (Brigham et al. 2009).

The Adirondack region of New York is a largely forested and mountainous area with abundant lakes, streams, and wetlands. Surface waters in this region have been the frequent focus of investigations because of high sensitivity to acidification from acid deposition, and also due to high levels of $\mathrm{Hg}$ measured in surface waters and biota (Jenkins et al. 2005; Evers et al. 2007). Studies in Adirondack surface waters similar to those in nearby New England and southeastern Canada have shown a strong association of dissolved $\mathrm{Hg}$ and DOC concentrations (Driscoll et al. 1995; Selvendiran et al. 2009; Dittman et al. 2010). Many previously published investigations, however, have focused on small catchments or small lakes with drainage areas of only a few $\mathrm{km}^{2}$, and relatively homogeneous forested landscapes. Here, we describe results of a study in the $493 \mathrm{~km}^{2}$ upper Hudson River basin, which drains a largely forested area of diverse topography that includes mountainous terrain and riparian floodplains dominated by wetlands as well as numerous lakes and ponds interconnected by streams and rivers. Recently published studies in this basin have shown a relatively weak correlation between total $\mathrm{Hg}(\mathrm{THg})$ and DOC concentrations that varies 
seasonally and with flow (Bushey et al. 2008; Schelker et al. 2011; Burns et al. 2012), though some data in this basin indicate a strong $\mathrm{Hg}-\mathrm{DOC}$ relation (Selvendiran et al. 2009; Dittman et al. 2010). We argue that the diverse landscape in this basin results in a range of organic matter sources and sinks that greatly affect the cycling of $\mathrm{Hg}$ and preclude the strong correlation between dissolved $\mathrm{Hg}$ and DOC concentrations often observed in smaller more homogeneous basins in this region. Here, we build on previous work that indicated specific ultra-violet absorbance at $254 \mathrm{~nm}\left(\mathrm{SUVA}_{254}\right)$ was a stronger predictor of variation in $\mathrm{THg}$ concentrations than were DOC concentrations during the summer across the upper Hudson basin (Burns et al. 2012). We hypothesize that SUVA $_{254}$ is a potentially powerful predictor of dissolved $\mathrm{Hg}$ concentrations because this measure reflects the source areas and landscape locations where DOC and $\mathrm{Hg}$ interactions occur as well as the relative aromaticity and ability of the DOC to bind and transport $\mathrm{Hg}$. Furthermore, we use a multiple regression spatial modeling approach to examine the relative influence of DOC concentrations and $\mathrm{SUVA}_{254}$ values on $\mathrm{Hg}$ concentrations, and use a similar approach to explore the landscape elements that most greatly affect variation in $\mathrm{SUVA}_{254}$ values. The results reported here may differ from those in small catchments because the $\mathrm{Hg}$ cycle in larger heterogeneous basins is affected by a diverse array of landscape types and varied sources and sinks of organic matter. Studies of $\mathrm{Hg}$ cycling in larger basins are important because these surface waters are more likely to have complex food webs that extend to larger carnivorous fish, which tend to have the highest $\mathrm{Hg}$ levels, and therefore pose the greatest human health risk.

\section{Study site}

The upper Hudson River is defined here as the $492.8 \mathrm{~km}^{2}$ basin upstream of the U.S. Geological Survey gage near Newcomb, NY in the Adirondack State Park (Fig. 1). Fishing Brook at County Line Flow is a $65.6 \mathrm{~km}^{2}$ sub-basin that defines the

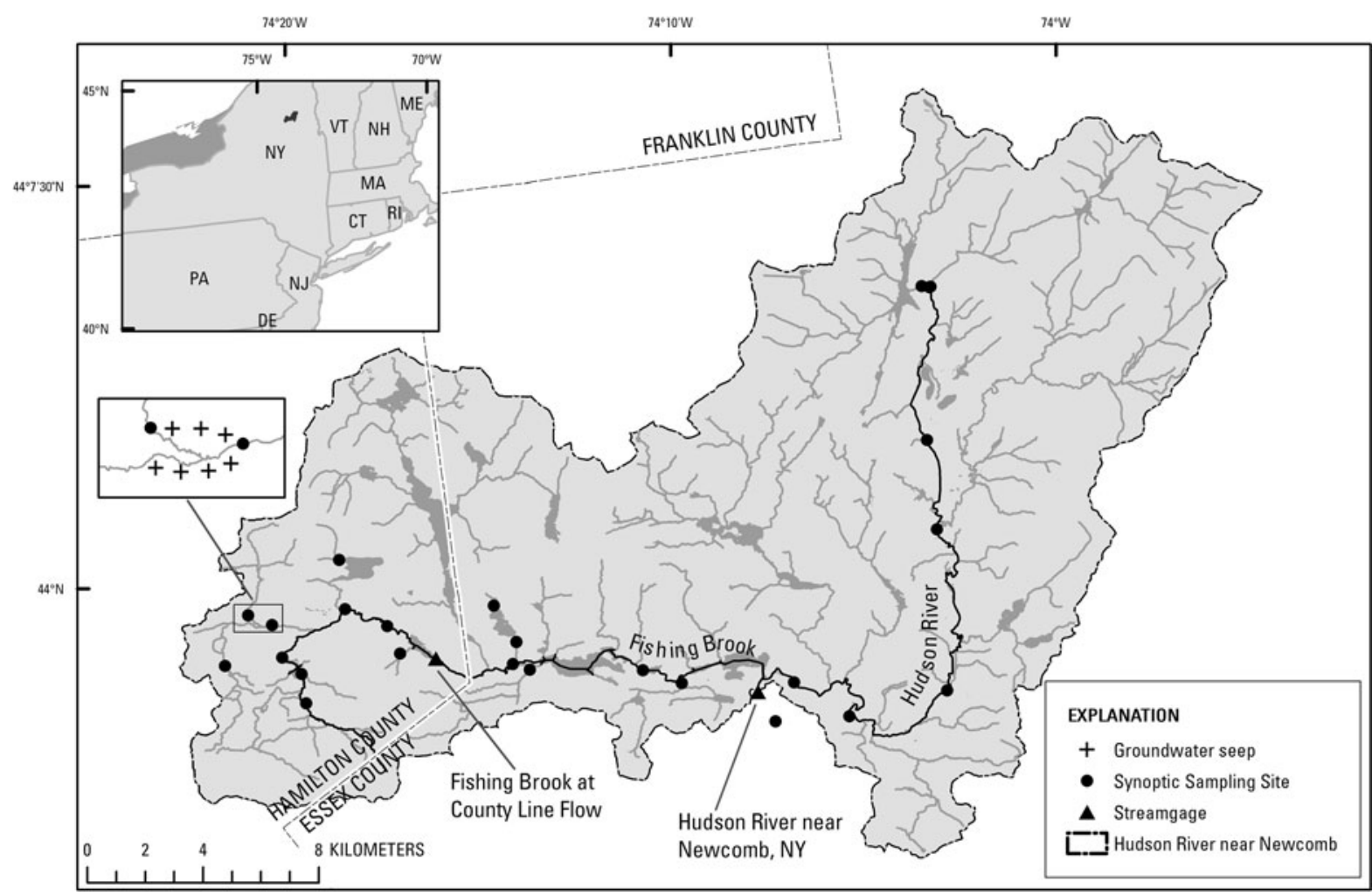

Fig. 1 Map showing gaged stream sampling sites, Fishing Brook at County Line Flow and the Hudson River near Newcomb as well as 25 additional synoptic sampling sites discussed in paper. Locations of seven groundwater seeps shown on inset map 
westernmost boundary of the upper Hudson basin (Fig. 1). The upper Hudson basin is underlain by metamorphic bedrock of middle Proterozoic age (Chiarenzelli and McLelland 1993). There are distinct steep (mean slope $=30 \%$ ) upland areas in the northernmost and westernmost parts of the basin overlain by coarse rocky till with exposed bedrock, and riparian floodplains that are dominant at lower elevations in the basin overlain by sandy outwash and alluvium with intermixed discontinuous peat (NRCS 2006, 2010). Much, though not all of this riparian area is classified as wetland; $6.7 \%$ of the basin is wetland area (LaPoint et al. 2004; Dahl et al. 2009). The basin also has many ponds and lakes; $3.6 \%$ of the basin is classified as open water (excluding wetland area; 1:24,000 National Hydrography Dataset; http://nhd. usgs.gov/data.html; accessed 17 Jan 2012). The basin is largely forested (92 \%) (1992 National Land Cover Dataset; http://landcover.usgs.gov/natllandcover.php; accessed 17 Jan 2012), with $<1 \%$ developed land. Elevation ranges from 423 to $1624 \mathrm{~m}$. The basin is in the southernmost part of the Eastern forest-boreal transition ecoregion (Olson et al. 2001), and is dominated by northern hardwood forest below $1,000 \mathrm{~m}$ and spruce-fir at higher elevations and in wet areas adjacent to surface waters.

\section{Methods}

Two principal data sets were analyzed in this paper: (1) $\mathrm{Hg}$ and organic carbon fraction concentrations in 43 stream samples collected from Fishing Brook at County Line Flow approximately every 3 weeks for 33-months from Jan 2007 to Sept 2009, and (2) SUVA $_{254}$ values in 54 synoptic stream samples collected at 27 catchments scattered across the upper Hudson basin during spring (May) and summer (July and Aug) of 2006 and 2008. Data from the Fishing Brook gage were analyzed in sum and by season (dormant Nov 1-Apr 30, growing May 1-Oct 31) because seasonal patterns were observed in past analyses at this site (Schelker et al. 2011). Additionally, results from 22 samples collected at 7 groundwater seeps located in the largest riparian wetland within Fishing Brook (Fig. 1) are also discussed. Sampling, analytical, and data analysis methods for these samples are described below.
Field sampling

Fishing Brook was sampled at the outlet of County Line Flow, a small shallow impoundment just upstream of the USGS stream gage that recorded stage at 15-min intervals for conversion to streamflow through a rating curve (Rantz et al 1982). All stream samples were collected by wading to the center point of flow or reaching to the center of flow when channels were narrow or to sample groundwater seeps. Each bottle was rinsed three times with stream water before filling.

A trace metal sampling technique similar to EPA Method 1669 (US EPA 1996) was used for $\mathrm{Hg}$ that employed wrist-length nitrile (use of name brands in this paper is for identification purposes only and does not represent an endorsement by the U.S. government) gloves over shoulder-length polyethylene gloves. Samples were filtered through $0.7-\mu \mathrm{m}$ pore size, prebaked $\left(550{ }^{\circ} \mathrm{C}\right)$ quartz-fiber filters, acidified to approximately $1 \%$ with $6 \mathrm{~N} \mathrm{HCl}$, and stored in the dark until analysis. The filters were placed in sterile petri dishes and stored frozen on dry ice until analysis. Additional details about $\mathrm{Hg}$ sampling methods are provided in Lewis and Brigham (2004) and QA/QC details are described in Schelker et al. (2011) and Burns et al. (2012).

Samples for DOC and $\mathrm{UV}_{254}$ were pressure-filtered through baked glass fiber $0.7-\mu \mathrm{m}$ filters into $150 \mathrm{~mL}$ amber glass bottles and stored at $4{ }^{\circ} \mathrm{C}$ until analysis. The filter was also stored at $4{ }^{\circ} \mathrm{C}$ for later analysis of POC. Samples for HPOA analysis were passed through a $0.45-\mu \mathrm{m}$ capsule filter into $1 \mathrm{~L}$ amber glass bottles and similarly stored at $4{ }^{\circ} \mathrm{C}$ until analysis.

\section{Laboratory analyses}

Filtered total $\mathrm{Hg}$ (FTHg) and particulate total $\mathrm{Hg}$ (PTHg) were analyzed at the USGS Mercury Research Laboratory in Middleton, Wisconsin. Analysis of $\mathrm{Hg}$ was by cold vapor atomic fluorescence spectrometry according to the method described by Olson and DeWild (1999). THg is reported as the sum of FTHg and PTHg.

DOC concentrations, $\mathrm{UV}_{254}$ measurements, and DOC fractionation analyses were performed at the USGS Organic Carbon Laboratory in Boulder, Colorado. Dissolved organic carbon was analyzed on an OI Analytical Model 700 TOC analyzer (Aiken et al. 
1992). $\mathrm{UV}_{254}$ measurements (absorbance at $\lambda=$ $254 \mathrm{~nm}$ ) were made with a Hewlett-Packard Photodiode Array Spectrophotometer (model 8453) using a $10 \mathrm{~mm}$ quartz cell. $\mathrm{UV}_{254}$ data were corrected for the presence of iron $(\mathrm{Fe})$ by subtracting the absorbance resulting from $\mathrm{Fe}$ (III) from the total absorbance value using an extinction coefficient of 0.0687 ; note that this coefficient is less than the value of $0.081-0.085$ reported by Weishaar et al. (2003), and is based on more recent experimental data (B. Poulin personal communication). Analysis of $\mathrm{Fe}$ was done at the USGS National Water Quality Laboratory by Inductively-Coupled Plasma Emission Spectroscopy (USGS Method 01046, https:Ilwww.nemi.gov; accessed 17 Jan 2012). SUVA 254 values were obtained by dividing the corrected $\mathrm{UV}_{254}$ value by the DOC concentration (mg C/L) and are reported in units of $\mathrm{L} / \mathrm{mg} \mathrm{C} / \mathrm{m}$. The HPOA fraction was obtained following established protocols (Aiken et al. 1992; Spencer et al. 2010). In brief, samples were acidified to $\mathrm{pH} 2$ with $\mathrm{HCl}$ and passed through a column of XAD-8 resin. The HPOA fraction was retained on the XAD- 8 resin and then back eluted with $0.1 \mathrm{M} \mathrm{NaOH}$. The percent HPOA was determined by dividing the HPOA concentration by that of DOC. POC was analyzed at the USGS National Water Quality Laboratory by high temperature combustion according to EPA Method 440.0 (https: Ilwww.nemi.gov; accessed 17 Jan 2012).

\section{Landscape metrics}

The landscape metrics explored for inclusion in multiple regression models that best predict $\mathrm{SUVA}_{254}$ values across the 27 synoptic sites are the same as those discussed previously by Burns et al. (2012) for modeling $\mathrm{THg}$ and $\mathrm{MeHg}$ in the same basin. All of these metrics are described in Supplemental Table S-1, but only those that appeared in the best models are described here.

Landscape metrics were compiled for each subbasin by geographic information system (GIS) analyses using Arc GIS software. The mean slope and mean topographic wetness index (TWI) were calculated for each sub-basin by terrain analysis of the $10 \mathrm{~m}$ National Elevation Dataset (http://seamless.usgs.gov, accessed 17 Jan 2012) using the System for Automated Geoscientific Analyses (SAGA, http://www. saga-gis.org/en/index.html, accessed 17 Jan 2012; Cimmery 2007). The TWI, $\ln (a / \tan \beta)$, was first defined by Beven and Kirkby (1979), in which $a$ is accumulated area per unit contour length and $\beta$ is the local slope angle. Riparian area (expressed as proportion of total basin area and termed ripct) was calculated in SAGA by including all cells contributing to a given stream cell within an elevation $<0.65 \mathrm{~m}$ above the stream cell. Wetland land cover was derived from the Adirondack Park Agency coverage, in which wetlands were delineated from 1:40,000 color infrared aerial photographs according to the approach used in the National Wetlands Inventory (Dahl et al. 2009; LaPoint et al. 2004).

Basin percent open water area is a commonly applied metric in studies of spatial controls on $\mathrm{Hg}$ cycling (Hurley et al. 1995; Shanley et al. 2005), and was explored here for inclusion in multiple regression models. An alternative to this metric, the open water index (OWI) that accounts for the proportion of basin drainage area that transits each open water body $>0.025 \mathrm{~km}^{2}$ was also calculated (described in greater detail by Burns et al. 2012). The remaining small open water bodies ( $<0.025 \mathrm{~km}^{2}$ each) were compiled into a separate small open water body surface area metric for each sub-basin.

\section{Statistical analyses}

Multiple linear regression models were developed (SigmaStat software) to explore how well DOC concentrations and $\mathrm{SUVA}_{254}$ values together explained variation in FTHg concentrations at Fishing Brook at County Line Flow. A forward stepwise method was applied, and both independent variables were significant ( $p \leq 0.05$, with one noted exception) for all models discussed in the text. Additional multiple linear regression models were explored to determine which combination of the landscape metrics shown in Supplemental Table S-1 could best explain the variation in $\mathrm{SUVA}_{254}$ values across the 27 synoptic sites in the upper Hudson basin. Models were explored for every possible combination up to eight variables. A sequence of steps was then followed to select the "best" model. First, any models in which the $p$ value of one of the independent variables was $>0.05$ were rejected. Second, any models that included a variance inflation factor (VIF) $>4.0$, a conservative level (O'Brien 2007), were rejected. The VIF is a measure of the proportion of variance accounted for by a given variable relative to the other independent variables in 
the model, and thus can help avoid including variables with high multi-collinearity, a common occurrence for landscape metrics. In general, any model with more than four predictive variables was rejected based on either $p>0.05$ or VIF $>4.0$. Any models remaining after these two steps were further evaluated by selecting those with the highest $R^{2}$ values for each incremental number of independent variables, and then applying Akaike's Information Criteria to select the best model with the least number of independent variables.

\section{Results and discussion}

Seasonal variation in $\mathrm{Hg}$ and organic carbon measures

$\mathrm{THg}$ concentrations ranged from 1.3 to $3.9 \mathrm{ng} / \mathrm{L}$ (mean $=2.4 \mathrm{ng} / \mathrm{L})$ in Fishing Brook during the study period of Jan 2007-Sept 2009 (Fig. 2a). The closeness of the symbols for THg and FTHg in Fig. 1a indicate that the $\mathrm{THg}$ fraction is dominated by filtered $\mathrm{Hg}$. Mean FTHg/THg was $83.2 \%$ and never less than $65 \%$ in any sample collected. Similarly, the TOC and DOC symbols are quite close in Fig. 2a, and mean DOC/TOC was $94.4 \%$ in Fishing Brook. Due to the dominance of the dissolved fractions for both $\mathrm{THg}$ and $\mathrm{TOC}$, the analysis in this paper focuses on interpreting variation in DOC and FTHg concentrations.

Clear seasonal variation is apparent in the annual patterns of DOC and FTHg concentrations. For example, the highest annual DOC values of 9-12 $\mathrm{mg} / \mathrm{L}$ were observed during summer $(p<0.001)$, when streamflow is typically lowest for the year. This type of seasonal pattern in DOC concentrations is commonly observed in watersheds dominated by nearstream wetlands (Schiff et al. 1998; Ågren et al. 2008), presumably due to: (1) waning influence of steeper upland areas with shallow soils during the driest seasonal conditions, and (2) increased influence from shallow groundwater in near-stream riparian areas with high DOC concentrations, where water tables remain relatively high in summer (Vidon and Hill 2004). In contrast, the greatest DOC and TOC concentrations in upland watersheds that lack significant near-stream wetlands or peat commonly occur
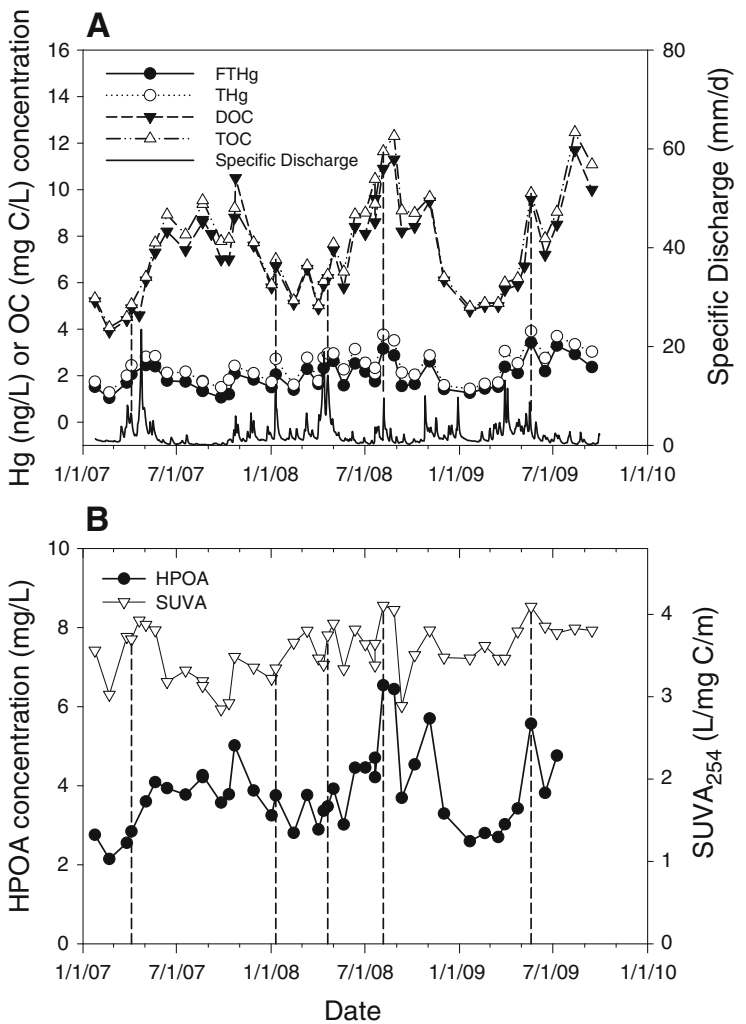

Fig. 2 Measures of $\mathrm{Hg}$ and $\mathrm{OC}$ in Fishing Brook at County Line Flow for samples collected during 2007-2009: a THg, FTHg, DOC, and TOC concentrations, b HPOA concentrations and $\mathrm{SUVA}_{254}$ values. The five vertical dashed lines indicate samples collected at or near hydrograph peaks and are discussed in text

during snowmelt and rain storms, driven by the flushing of organic carbon from shallow soils (Boyer et al. 1997; Hinton et al. 1997). Such watersheds often have low baseflow DOC concentrations of $1-5 \mathrm{mg} / \mathrm{L}$ with higher values during leaf fall (Mulholland 2003). Event-driven DOC flushing patterns are not readily apparent in Fishing Brook (Schelker et al. 2011). However, five samples collected at or near hydrograph peaks and marked with vertical dashed lines in Fig. 2a suggest that DOC concentrations sometimes increase during high flow relative to baseflow, though the broad seasonal pattern of higher concentrations during summer low flow appears stronger. This conclusion that seasonal dominance is a slightly stronger pattern than that of increases with flow during storms is confirmed by a significant $(p=0.036)$, but weak $\left(r^{2}=0.09\right)$ inverse least squares linear regression relation between $\log _{10}$ specific discharge and DOC 
Table 1 Linear regression relations for FTHg concentrations with organic carbon measures for all samples, dormant season, and growing season at Fishing Brook at County Line Flow during 2007-2009

\begin{tabular}{|c|c|c|c|c|c|c|c|c|c|}
\hline \multirow[t]{2}{*}{ Organic carbon measure } & \multicolumn{3}{|l|}{ All } & \multicolumn{3}{|c|}{ Dormant season (Nov 1-Apr 30) } & \multicolumn{3}{|c|}{ Growing season (May 1-Oct 31) } \\
\hline & $r^{2}$ & $p$ value & Slope & $r^{2}$ & $p$ value & Slope & $r^{2}$ & $p$ value & Slope \\
\hline DOC conc. & 0.31 & $<0.001$ & 0.17 & 0.42 & 0.003 & 0.24 & 0.25 & 0.013 & 0.22 \\
\hline $\mathrm{UV}_{254}$ & 0.53 & $<0.001$ & 5.40 & 0.50 & $<0.001$ & 6.57 & 0.57 & $<0.001$ & 6.73 \\
\hline HPOA conc. & 0.42 & $<0.001$ & 0.39 & 0.47 & 0.001 & 0.42 & 0.42 & 0.001 & 0.50 \\
\hline HPOA \% & 0.21 & 0.002 & 0.079 & 0.14 & 0.11 & 0.077 & 0.49 & $<0.001$ & 0.12 \\
\hline SUVA & 0.63 & $<0.001$ & 1.51 & 0.27 & 0.02 & 1.14 & 0.82 & $<0.001$ & 1.57 \\
\hline
\end{tabular}

concentrations for all samples collected at Fishing Brook; weak flow relations with DOC are a common finding in wetland-impacted streams (Hinton et al. 1997).

FTHg concentrations also were generally higher during the growing season than during the dormant season at 27 stream sites across the upper Hudson basin (Burns et al. 2012). Unlike DOC, however, FTHg concentrations increased with streamflow, a pattern observed during five different high flow periods marked with vertical dashed lines in Fig. 2a. Streamflow ( $\log _{10}$ specific discharge) was significantly $(p=0.024)$ and positively related to FTHg concentrations, consistent with a source from flushing of shallow soils as hypothesized by Schelker et al. (2011), but this relation is relatively weak $\left(r^{2}=0.12\right)$, and explains little of the annual variation at Fishing Brook.

Some seasonality and response to flow conditions was observed in HPOA concentrations and $\mathrm{SUVA}_{254}$ values, but the patterns of the two differed (Fig. 2b). SUVA $_{254}$ values sometimes followed the pattern of HPOA concentrations as in the latter half of 2008 and 2009, but sometimes show strikingly different patterns as in 2007. Overall, SUVA $_{254}$ values and HPOA concentrations are significantly $(p=0.006)$ positively correlated, but the $r^{2}$ value of 0.18 indicates a relatively weak relation. This relation improves only slightly to an $r^{2}$ value of $0.22(p=0.002)$ when SUVA $_{254}$ values are regressed with those of HPOA percent. Furthermore, SUVA 254 values are even less strongly correlated with those of DOC concentrations $(p=0.10$, $\left.r^{2}=0.06\right)$ indicating independent variation among these two variables. In contrast, HPOA concentrations are highly correlated with those of DOC concentrations ( $\left.p<0.001, r^{2}=0.92\right)$ indicating strong seasonal synchronicity among these two quantities.
Relation of FTHg concentrations to organic carbon measures

FTHg concentrations are significantly related to all of the organic carbon measures at Fishing Brook as determined by linear regression; however, $\mathrm{SUVA}_{254}$ values show the strongest relation with an $r^{2}$ value of 0.63 for all samples collected (Table 1; Fig. 3b). FTHg concentrations are more strongly related to SUVA $_{254}$ values than any of the other organic matter measures, including $\mathrm{UV}_{254}$, HPOA concentration, and HPOA percent (Table 1). These results contrast with those of Dittman et al. (2009) for three northeastern U.S. streams in which FTHg concentrations showed progressively stronger relations with DOC concentrations, HPOA concentrations, and $\mathrm{UV}_{254}$ values; $r^{2}$ values exceeded 0.90 for the latter two measures. In contrast to the strong relation between FTHg concentrations and $\mathrm{SUVA}_{254}$ values, FTHg concentrations and DOC concentrations show an $r^{2}$ value of only 0.31 at Fishing Brook (Table 1; Fig. 3a). This finding is especially surprising because FTHg concentrations and DOC concentrations in streams and lakes with largely forested watersheds in Sweden, the Adirondacks, northeastern US, and upper Midwest typically show stronger relations with $r^{2}$ values of 0.6-0.93 (Selvendiran et al. 2008, 2009; Shanley et al. 2008; Brigham et al. 2009; Dittman et al. 2009; Eklöf et al. 2012). However, previous investigations in Fishing Brook and the upper Hudson basin noted relatively weak $\mathrm{THg}-\mathrm{DOC}$ relations (Schelker et al. 2011; Burns et al. 2012). This lack of a strong $\mathrm{Hg}-\mathrm{DOC}$ relation was attributed in part to the role of numerous open waters as dynamic reactors where sunlight, biological uptake, microbial processes, and interactions with lake sediment combine to alter the characteristics of DOC with respect to $\mathrm{Hg}$ binding and 

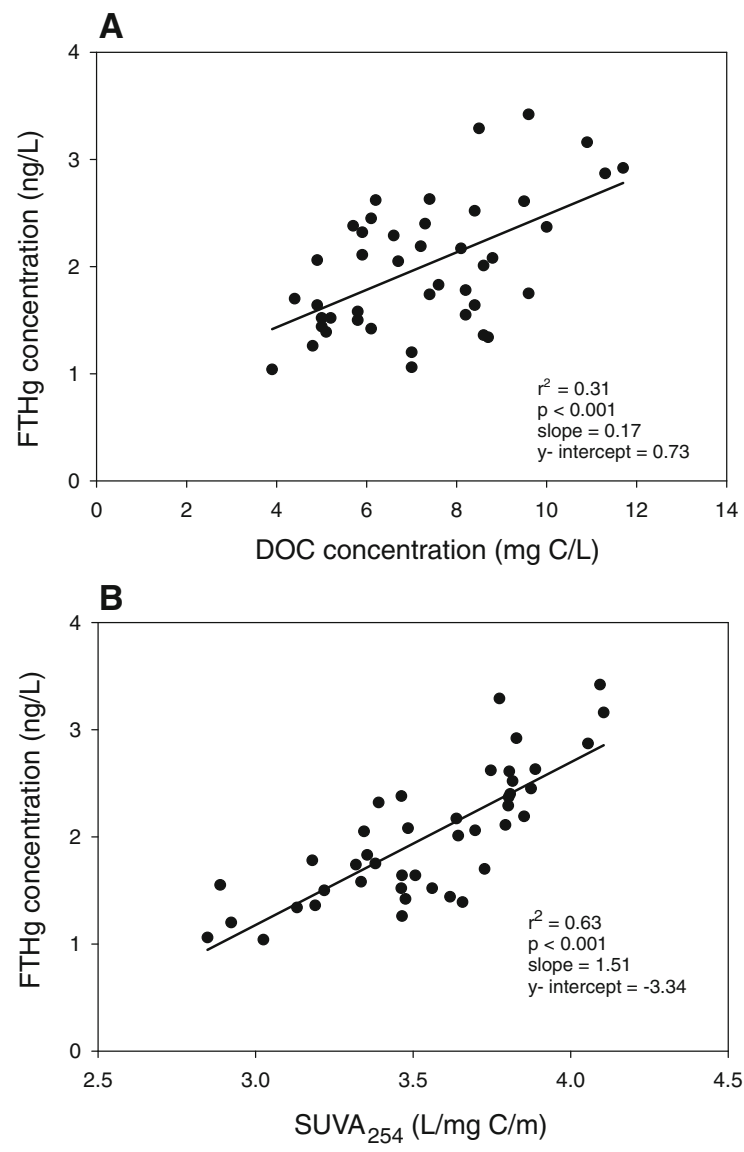

Fig. 3 FTHg concentrations and: a DOC concentrations, and b SUVA 254 values in Fishing Brook at County Line Flow for samples collected during 2007-2009. Bivariate linear regression relations are shown

to diminish THg concentrations (Schelker et al. 2011; Burns et al. 2012).

On first consideration, there is not a readily apparent reason why FTHg concentrations should be strongly related to $\mathrm{SUVA}_{254}$ values because this organic carbon measure reflects the relative aromaticity and molecular weight of the organic matter in a sample, but is not a concentration (Weishaar et al. 2003). This study is one of several, however, in which variation in $\mathrm{SUVA}_{254}$ values account for much of the variation in FTHg concentrations in surface waters (Table 2). Instances where the FTHg-SUVA 254 association is about as strong, or stronger than the FTHgDOC association tend to be from synoptic-type studies in which surface waters with diverse land cover have been sampled (Hall et al. 2008; Tsui and Finlay 2011; Burns et al. 2012), with the exception of the current study. In contrast, the FTHg-SUVA 254 relation tends to be relatively weaker than that of $\mathrm{FTHg}-\mathrm{DOC}$ or $\mathrm{FTHg}-\mathrm{UV}_{254}$ in watersheds with more uniform, largely forested upland land cover (Schuster et al. 2008; Dittman et al. 2010). Several studies in which $\mathrm{Hg}-\mathrm{DOC}$ relations were explored may not have also considered whether FTHg concentrations and SUVA $_{254}$ values were related because another measure such as DOC concentration, $\mathrm{UV}_{254}$, or HPOA concentration was able to explain most of the variation in FTHg (Shanley et al. 2008; Dittman et al. 2009; Riscassi and Scanlon 2011; Eklöf et al. 2012). Given these results, it seems pertinent to ask why FTHg concentrations and $\mathrm{SUVA}_{254}$ values are strongly related in many of these studies (Table 2). We hypothesize that $\mathrm{Hg}$ and $\mathrm{DOC}$ are transported to surface waters from a variety of contrasting source areas (and are also affected by sink areas such as lakes) that include riparian wetlands, forested uplands, open water and varying depths within soils. The source areas where DOC with the most aromatic character is mobilized are wetlands and in the shallowest soil horizons, which coincide with the dominant $\mathrm{Hg}$ mobilization zones as well. In this hypothesis, the mix of DOC and $\mathrm{Hg}$ from these source areas and the flow paths of water that moves these solutes to adjacent surface waters govern the apparent FTHgSUVA $_{254}$ association. An alternative hypothesis is that the more aromatic fraction of DOC has more thiol binding sites for $\mathrm{Hg}$ or more binding sites in general (Ravichandran 2004; Schuster et al. 2008; Riscassi and Scanlon 2011; Tsui and Finlay 2011). We favor the first hypothesis, primarily because a large excess of reduced sulfur groups is generally available for $\mathrm{Hg}$ binding in most natural settings (Haitzer et al. 2002), and this excess binding ability is not expected to be greatly affected by the relative mix of aromatic and aliphatic organic matter.

The $\mathrm{Hg}$-organic matter association varies by season; $\mathrm{SUVA}_{254}$ values account for more of the variation in FTHg concentrations during the growing season $\left(r^{2}=0.82, p<0.001\right)$ than the dormant season $\left(r^{2}=0.27, p=0.02\right)$ (Fig. 4). Conversely, FTHg concentrations are more weakly associated with DOC concentrations during the growing season than during the dormant season. $\mathrm{UV}_{254}$ values and HPOA concentrations show about the same association with FTHg concentrations during both seasons, and HPOA percent (like $\mathrm{SUVA}_{254}$ ) is more strongly related with 
Table 2 Summary of studies that have reported FTHg-SUVA 254 regression relations for surface waters

\begin{tabular}{|c|c|c|c|c|c|}
\hline Reference & Study location & $\begin{array}{l}\mathrm{DOC} \\
(\mathrm{mgC} / \mathrm{L})\end{array}$ & $\begin{array}{l}\mathrm{UV}_{254} \\
\text { (abs.) }\end{array}$ & $\begin{array}{l}\mathrm{SUVA}_{254} \\
(\mathrm{~L} / \mathrm{mgC} / \mathrm{m})\end{array}$ & Notes \\
\hline This study & Fishing Brook, NY & 0.31 & 0.53 & $0.63(2.8-4.2)$ & One site; year round; $n=43$ \\
\hline $\begin{array}{l}\text { Burns et al. } \\
\text { (2012) }\end{array}$ & Upper Hudson R, NY & 0.32 & NR & $0.42(1.6-4.5)$ & $\begin{array}{l}\text { Summer samples; } 25 \text { sites; sampled } \\
\text { once ea }\end{array}$ \\
\hline $\begin{array}{l}\text { Tsui and Finlay } \\
\text { (2011) }\end{array}$ & MN streams & 0.63 & NR & $0.86(2.6-4.8)$ & $\begin{array}{l}\text { Summer samples; } 30 \text { sites; sampled } \\
\text { once ea; regressions for } \log _{10} \text { FTHg }\end{array}$ \\
\hline $\begin{array}{l}\text { Dittman et al. } \\
\text { (2010) }\end{array}$ & $\begin{array}{l}\text { Archer Ck, NY; Hubbard Bk, } \\
\text { NH; Sleepers R, VT }\end{array}$ & 0.87 & 0.92 & $0.53(1.9-3.9)$ & $\begin{array}{l}\text { Sites pooled for analysis; year round; } \\
\text { total } n=128\end{array}$ \\
\hline Hall et al. (2008) & Lower Miss. R, LA & 0.69 & NR & $0.65(2.6-4.5)$ & $\begin{array}{l}\text { Lakes, rivers, and wetlands; } 21 \text { sites; } \\
\text { sampled four times ea }\end{array}$ \\
\hline $\begin{array}{l}\text { Schuster et al. } \\
\text { (2008) }\end{array}$ & Sleepers R, VT & 0.31 & NR & $0.07(1.3-4.0)$ & $\begin{array}{l}\text { Snowmelt samples; ten sites; total } \\
n=57 ; \text { SUVA }_{254} \text { relation for sub- } \\
\text { set of data }\end{array}$ \\
\hline
\end{tabular}

Values of $r^{2}$ for bivariate linear regressions of FTHg with DOC concentrations, $\mathrm{UV}_{254}$, and SUVA 254 . Approximate range of reported $\mathrm{SUVA}_{254}$ values in parentheses

FTHg concentrations during the growing season, but the relation is not as strong $\left(r^{2}=0.49, p<0.001\right)$ as that of the FTHg-SUVA 254 association. A previous investigation in the upper Hudson basin also found that $\mathrm{SUVA}_{254}$ accounted for more of the spatial variation in $\mathrm{THg}$ concentrations across 27 stream sites in summer than any other chemical metric (Burns et al. 2012), consistent with the results reported here.

\section{Multiple regression models to predict FTHg concentrations}

Burns et al. (2012) showed that multiple regression models that account for much of the variation in $\mathrm{THg}$ concentrations across the upper Hudson were stronger $\left(r^{2}=0.71-0.84\right)$ when DOC concentrations and SUVA $_{254}$ values were included as independent variables than models obtained through either metric alone, especially in summer. Results of a forward stepwise multiple regression model for the entire period at Fishing Brook indicate that DOC concentrations and $\mathrm{SUVA}_{254}$ values are each highly significant $\left(p<0.001\right.$, combined $\left.R^{2}=0.75\right)$, and indicate a modest improvement to the bivariate regression obtained with $\mathrm{SUVA}_{254}$ values $\left(r^{2}=0.63\right.$; Fig. 5a). The $\Delta R^{2}$ value for DOC concentrations in the multiple regression model is 0.12 , confirming that $\mathrm{SUVA}_{254}$ accounts for most of the variation in FTHg concentrations at Fishing Brook. This regression relation shows some bias by under-predicting at high FTHg concentrations and over-predicting at low FTHg concentrations. If $\log _{10}$ specific discharge is added to this model ( $p<0.001$ ), however, $R^{2}$ increases to 0.82 , and bias decreases (not shown). This model has relatively low VIF values $(<1.5)$ for all independent variables indicating that streamflow affects FTHg concentrations relatively independently of the other variables. SUVA 254 , however, still accounts for most of the annual variation in FTHg concentrations in the model that includes streamflow.

Seasonally, SUVA 254 values and DOC concentrations are less effective at predicting FTHg concentrations during the dormant season $\left(R^{2}=0.55\right)$ than the growing season $\left(R^{2}=0.84\right)$ (Fig. $\left.5 \mathrm{~b}, \mathrm{c}\right)$, though the dormant season model showed the most improvement relative to a bivariate regression with $\mathrm{SUVA}_{254}$ values. DOC concentrations explain more variation $\left(\Delta R^{2}=\right.$ $0.42, p=0.007)$ in FTHg concentrations during the dormant season than do $\operatorname{SUVA}_{254}$ values $\left(\Delta R^{2}=\right.$ $0.12, p=0.05)$, though both are significant dormant season predictors. This dormant season model shows greater bias than that of the annual model, underpredicting at high FTHg concentrations and overpredicting at low FTHg concentrations. In contrast, the stronger growing season model shows little bias, SUVA $_{254}$ is the dominant predictive variable $\left(\Delta R^{2}=0.82\right)$, and DOC concentrations add little predictive ability $\left(\Delta R^{2}=0.02, p=0.13\right)$. 


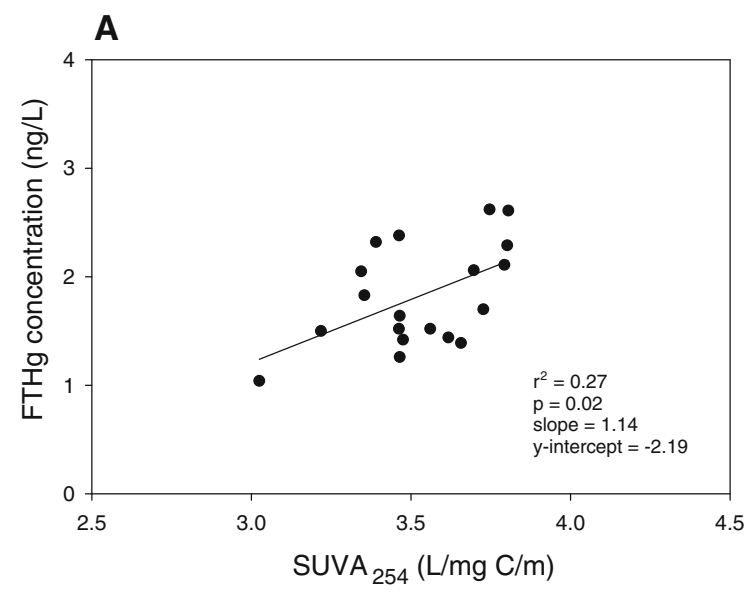

B

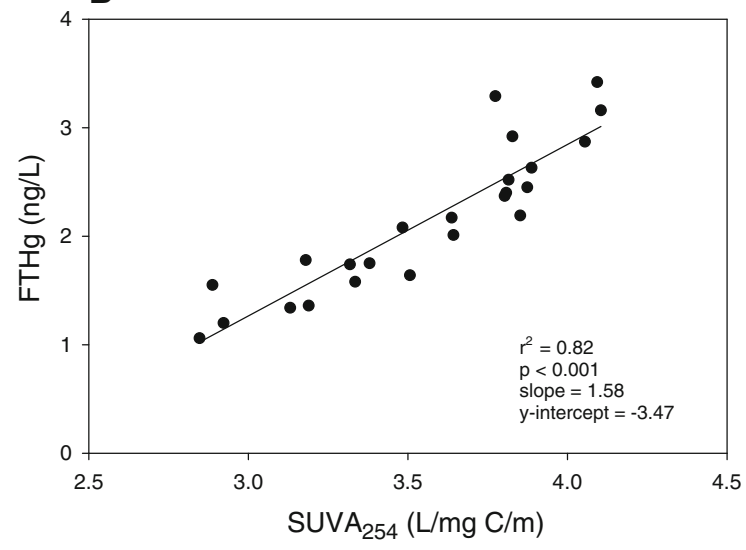

Fig. 4 FTHg concentrations and $\mathrm{SUVA}_{254}$ values for samples collected at Fishing Brook at County Line Flow in 2007-2009 for: a dormant season (Nov 1-Apr 30) and b growing season (May 1-Oct 31). Bivariate linear regression relations are shown

The role of streamflow as an additional predictive variable in these models is quite different by season. The $\log _{10}$ specific discharge does not improve $R^{2}$ values for the best growing season model, and has very low significance $(p=0.93)$, whereas $\log _{10}$ specific discharge is highly significant in the best dormant season model $(p<0.001)$. This latter model has an $R^{2}$ value of 0.89 , a strong improvement over the model that includes only the organic carbon measures (Fig. 5b). The low VIF value (1.1) for streamflow in the best dormant season model indicates that this variable accounts for variation in FTHg concentrations independently of the carbon measures. This finding is consistent with an hypothesis from earlier work at Fishing Brook that $\mathrm{Hg}$ is flushed from the shallow soil, primarily in riparian wetland areas during snowmelt and rain events, most evidently during the

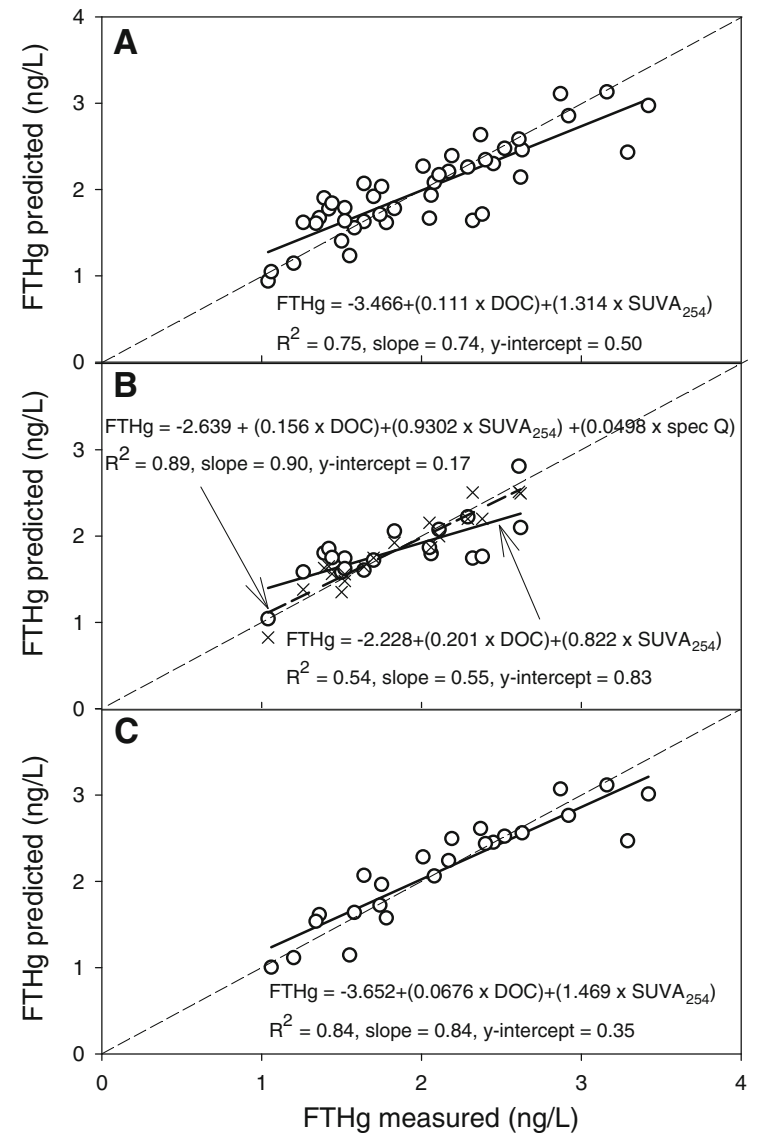

Fig. 5 Measured and predicted FTHg concentrations for Fishing Brook at County Line Flow for samples collected during 2007-2009 for: a entire period, b dormant season (Nov 1-Apr 30), and $\mathbf{c}$ growing season (May 1-Oct 31). Predicted values were derived from multiple linear regression models with DOC concentrations and SUVA $_{254}$ values as independent variables, except for an additional regression model shown in b with specific discharge (Q) included as an additional independent variable. Regression equations and $R^{2}$ values are shown in each panel and represented by a solid line, except for added model with Q shown as long dashed line. Dashed lines indicate slope of 1. Data point symbols represented by hollow circles except for model with $\mathrm{Q}$ in $\mathbf{b}$, represented by the times symbol. All regression equations are highly significant $(p<0.001)$

dormant season, and that this flushing mechanism appears to be independent of variations in DOC concentrations (Schelker et al. 2011), which are inversely and weakly related to flow as stated previously. In contrast, variation in growing season FTHg concentrations in Fishing Brook is strongly associated with variation in $\mathrm{SUVA}_{254}$ values, with little influence from either DOC concentrations or flow. This finding raises important questions as to the source areas and 
processes that affect variation in $\mathrm{SUVA}_{254}$ values in this basin, which are explored further in the next section.

\section{Relation of $\mathrm{SUVA}_{254}$ values to landscape metrics}

Given the apparent importance of $\mathrm{SUVA}_{254}$ values in explaining growing season variations in FTHg concentrations at Fishing Brook, the role of several landscape metrics are explored here to gain insight to the sources of variation in $\mathrm{SUVA}_{254}$ values across the upper Hudson basin. Multiple regression models that best account for variation in $\mathrm{SUVA}_{254}$ values were developed for synoptic samples collected at 27 stream sites across the upper Hudson River basin during 2006 and 2008 (Fig. 1). These sites range from steep upland watersheds to lowland streams with abundant riparian wetlands and varying influence from numerous open water bodies in the basin and are described in greater detail by Burns et al. (2012). Several of these sampling sites are within the Fishing Brook watershed discussed previously.

SUVA $_{254}$ values for synoptic samples collected in spring are well explained $\left(R^{2}=0.89\right)$ by a model that includes slope, percent riparian area (ripct), and an OWI (Fig. 6a). SUVA 254 values are highly correlated $(p<0.001)$ in bivariate regressions with slope (inversely), and percent riparian area; $r^{2}=0.82$ and 0.70 , respectively. In contrast, $\mathrm{SUVA}_{254}$ values are not strongly correlated ( $p=0.23$ ) with OWI in a bivariate regression, but this metric is significant $(p=0.02$, $\left.\Delta R^{2}=0.04\right)$ in the best multiple regression model indicating a minor role for open water. These springtime results suggest that higher $\mathrm{SUVA}_{254}$ values originate from soils in areas with gentler slopes, and in riparian areas that are commonly occupied by wetlands (percent wetland area strongly correlated $\left(r^{2}=0.66\right)$ with $\left.\mathrm{SUVA}_{254}\right)$, and a secondary role for open waters as a source of lower SUVA $_{254}$ values. These results are consistent with those of previous investigations in Oregon and in Sweden that have found higher $\mathrm{SUVA}_{254}$ values associated with riparian/wetland areas than values derived from forested upland areas (Hood et al. 2006; Ågren et al. 2008).

The multiple regression modeling results for synoptic samples collected in summer show some differences with those collected in spring (Fig. 6b). The best model in summer has an $R^{2}$ of only 0.49 , shows some bias (high at low $\mathrm{SUVA}_{254}$, low at high $\mathrm{SUVA}_{254}$ ), and indicates that about half the variation in $\mathrm{SUVA}_{254}$ values cannot be accounted for by these landscape metrics. This model includes slope and OWI as in the spring model, but also includes TWI and the small open water metric. Both accumulated area (analogous to drainage area) and slope are part of the TWI calculation, and reflect the tendency for a higher water table as values increase (Beven and Kirkby 1979). The TWI is inversely related $\left(r^{2}=0.19\right.$, $p=0.02$ ) to slope in the upper Hudson basin, but is more strongly (and positively) related to the percent open water in each sub-basin $\left(r^{2}=0.27, p=0.006\right)$, indicating that basins with high TWI values have gentler slopes, but also more open water. These two influencing factors are expected to have opposing effects on SUVA $_{254}$ values.
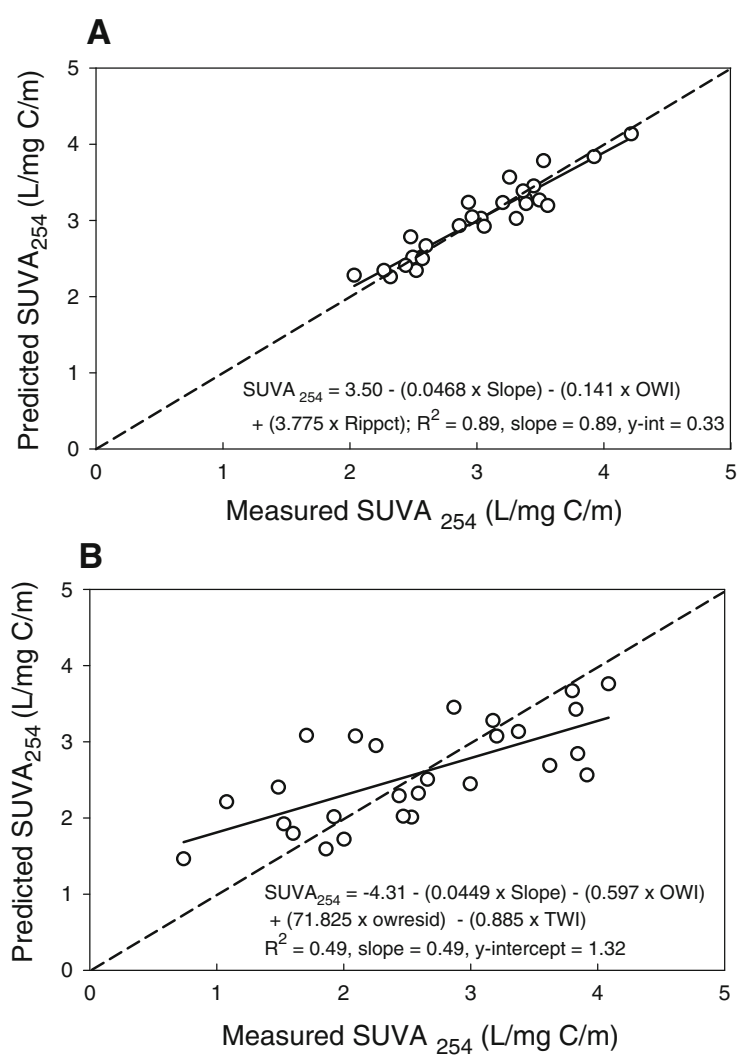

Fig. 6 Measured and predicted $\mathrm{SUVA}_{254}$ values for synoptic samples collected during 2006 and 2008 at 27 surface water sites in the Upper Hudson River basin: a spring (May), and $\mathbf{b}$ summer (July and Aug). Predicted values were derived from multiple linear regression models that considered several landscape metrics as discussed in text. Regression equations and $R^{2}$ values are shown in each panel and represented by a solid line. Dashed lines indicate slope of 1 . Regression in a is highly significant, $p<0.001$, regression in $\mathbf{b}$ is significant, $p=0.004$ 
Overall, three of four independent variables in the multiple regression model for $\mathrm{SUVA}_{254}$ based on summer synoptic samples are related in part to open water influence, and suggest stronger influence of open water on $\mathrm{SUVA}_{254}$ values in summer than in spring. The inverse relations with OWI and TWI indicate open water is associated with lower $\mathrm{SUVA}_{254}$ values. This finding suggests that low $\mathrm{SUVA}_{254}$ values may be derived in part from autochthonous processes such as decomposition of algae in the water column (Zumstein and Buffle 1989; Rostan and Cellot 1995). Photodegradation of allochthonous DOC may also contribute to declining $\mathrm{SUVA}_{254}$ values associated with open water influence (Minor and Stephens 2008). Regardless of the processes responsible, $\mathrm{SUVA}_{254}$ values often reach a minimum and the influence of autochthonous DOC reaches a maximum during summer low flow, particularly in lake-influenced systems (Zumstein and Buffle 1989; Hood et al. 2005) when sunlight and water temperature are at seasonal maximum values, consistent with the results presented here for summer synoptic samples. In contrast, the positive relation of $\mathrm{SUVA}_{254}$ values with the small open water variable is consistent with observations that these open waters are commonly beaver ponds or transitional wetlands in this basin, and thus behave more similarly to wetlands as a source of $\mathrm{Hg}$ (Driscoll et al. 1998) and higher SUVA 254 values.

Although synoptic samples were generally collected during similar low-to-moderate flow conditions, flows were greater in spring $($ mean $=1.8 \mathrm{~mm} /$ day, $\mathrm{RSD}=55 \%$ ) than in summer (mean $=1.3 \mathrm{~mm} /$ day, $\mathrm{RSD}=109 \%$ ). Because DOC and $\mathrm{Hg}$ concentrations are often strongly related to streamflow and the latter may be similarly strongly related to $\mathrm{SUVA}_{254}$ values (Hood et al. 2006; Schuster et al. 2008; Dittman et al. 2010), specific discharge was considered as a potential additional explanatory variable in the best multiple regression $\mathrm{SUVA}_{254}$ models. Consideration of streamflow is further reinforced by a significant bivariate regression relation $\left(r^{2}=0.32, p=0.002\right)$ between SUVA $_{254}$ values and specific discharge for samples collected during the growing season at Fishing Brook. However, specific discharge was not significant $(p>0.05)$ in either spring or summer multiple regression synoptic models. Thus, inclusion of flow did not improve model predictions from those obtained with just landscape metrics. This analysis has limitations, however, because these synoptic samples do not well represent high flow conditions, nor is the role of storms reflected by the samples.

SUVA $_{254}$ values are significantly inversely correlated with streamflow for samples collected in spring $\left(r^{2}=0.36, p=0.002\right)$, and positively correlated for samples collected in summer $\left(r^{2}=0.26, p=0.006\right)$. This difference may reflect the wetter conditions and higher water tables in this basin during spring than summer (Schelker et al. 2011). A previous study in Sweden in a similar heterogeneous landscape of upland forests and lowland riparian wetlands concluded that runoff in spring from forested upland areas (with lower $\mathrm{SUVA}_{254}$ values than in riparian areas) has a greater influence on stream DOC, and $\mathrm{SUVA}_{254}$ accordingly decreased with flow ( $⿱$ gren et al. 2008). During summer, in contrast, when riparian saturation deficits are greatest, riparian influence increased with flow, and $\mathrm{SUVA}_{254}$ values accordingly increased with flow.

There are clearly sources of variation in $\mathrm{SUVA}_{254}$ values not fully captured by models derived from the landscape metrics explored here, as evidenced by the $R^{2}$ value of 0.49 for summer samples. Carbon chemistry is complex with multiple molecular structures identified in DOC (Leenheer and Croué 2003), but the success of the modeling approach employed here, particularly for the spring synoptic samples, points to the principal sources of variation in $\mathrm{SUVA}_{254}$ as it represents the relative aromaticity of DOC and strong association with $\mathrm{Hg}$. A broad pattern of SUVA $_{254}$ values across the 27 sub-basins is observed when these data are divided into quartiles by percent riparian area and compared with groundwater seep samples collected in the largest riparian wetland area in the Fishing Brook basin (Fig. 7a). An analysis of variance on ranks (because data did not pass test for normality) indicated a statistically significant difference $(p<0.001)$ among these groups. Pairwise comparisons, however, showed that not all quartiles are statistically distinct, but that $\mathrm{SUVA}_{254}$ values generally increase as riparian area increases. The highest and most distinct values are in the uppermost quartile and in the groundwater seeps, the latter of which may be viewed as a "pure" riparian wetland source of DOC. The range in median $\mathrm{SUVA}_{254}$ values across the quartiles and seeps is about $1.5 \mathrm{~L} / \mathrm{mg} \mathrm{C} / \mathrm{m}$.

Open water influence on $\mathrm{SUVA}_{254}$ values can be similarly observed by examining the synoptic data by quartiles of the OWI (Fig. 7b). An analysis of variance 
A
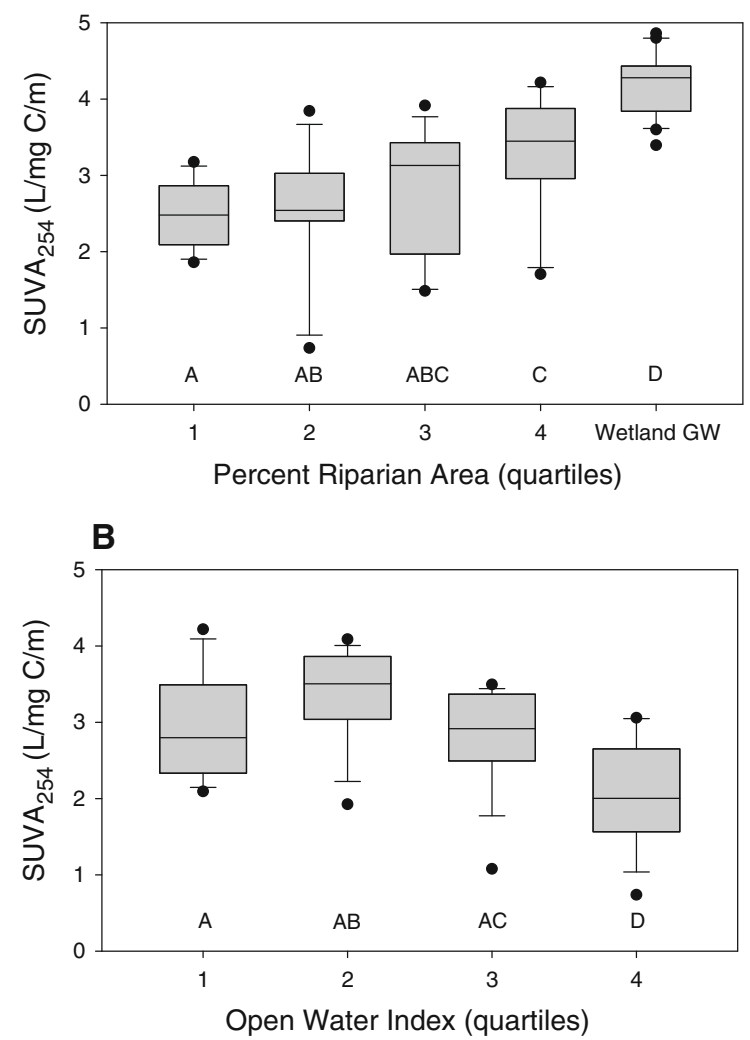

Fig. 7 Box plots of data from Upper Hudson River basin: a SUVA 254 values by percent riparian area quartiles for synoptic samples collected during 2006 and 2008 at 27 surface water sites and in wetland groundwater seeps collected during 2007-2009, and b SUVA 254 values by OWI quartiles for same synoptic samples shown in a. Capital letter designations below each box indicate statistical similarity and differences among pairwise comparisons of each quartile or group

indicated a statistically significant difference among these quartiles. A general decrease in $\mathrm{SUVA}_{254}$ values is observed across the quartile range, with the exception of the first to second quartiles. The highest quartile shows the lowest and statistically most distinct SUVA $_{254}$ values (based on pairwise comparisons) similar to that observed for the highest percent riparian area quartile. Also, the range in median values among the OWI quartiles is slightly greater than that of the percent riparian area quartiles.

\section{Relevance of results to methyl $\mathrm{Hg}$ transport}

Although the analysis above focused on FTHg, filtered methyl Hg (FMHg) concentrations were also measured in the larger study from which this paper is derived, and these data have been discussed in previous papers (Bradley et al. 2011; Schelker et al. 2011; Burns et al. 2012). Broadly, FMHg concentrations are significantly related $(p<0.05)$ with FTHg concentrations and with $\mathrm{SUVA}_{254}$ values. These relations, however, do not have strong explanatory ability $\left(r^{2}=0.1-0.2\right)$, reflecting the influence of different processes that control the production of FMHg and FTHg as well as varying dependence on organic carbon fractions for transport of these $\mathrm{Hg}$ species to surface waters. Nonetheless, the discussion of FTHg transport is believed to have some broad transfer value to understanding FMHg transport as well because FTHg may be later transformed to FMHg.

\section{Conclusions}

The results of this study indicate an important role for $\mathrm{SUVA}_{254}$ as a predictor of temporal and spatial variation in FTHg concentrations in the upper Hudson River basin. At Fishing Brook, SUVA $_{254}$ values explained twice the annual variation of FTHg concentrations than could be explained by DOC concentrations. Multiple regression models that included both variables accounted for an even greater amount of this variation in FTHg concentrations for all samples collected at Fishing Brook, but especially during the Nov-Apr dormant season. SUVA 254 alone, however, was a notably stronger predictor of FTHg concentrations in the May-Oct growing season. This seasonal difference is believed to result largely from the opposing influence of (1) gentler slopes and more extensive riparian area as a source of higher $\mathrm{SUVA}_{254}$ values and FTHg concentrations, and (2) open water as a source (with the exception of small open water bodies) of lower $\mathrm{SUVA}_{254}$ values and FTHg concentrations. These data are also consistent with an additional role for increasing contributions of runoff originating from shallow flow paths during events associated with greater $\mathrm{SUVA}_{254}$ values and FTHg concentrations; however, the relationships of SUVA $_{254}$, DOC, and FTHg with streamflow are relatively weak, suggesting that flow paths alone are only a minor explanatory variable (though samples collected in this study may not have adequately characterized stormflow). We believe these results generally reflect the manner in which the seasonal 
dynamics of upland versus riparian runoff sources combine with open water influence and flow-related variation to produce an apparent FTHg-SUVA relation. The aromaticity of DOC associated with higher SUVA $_{254}$ values may contribute to the patterns observed here, but is probably not the most important factor because of the excess of strong $\mathrm{Hg}$-binding sites generally available on DOC regardless of its relative aliphatic versus aromatic character. We believe these findings are especially pertinent to larger heterogeneous basins that encompass uplands, riparian wetlands, and open water bodies such as those commonly found in the northeastern US, southeastern Canada, and the upper Midwestern US (Lehner and Döll 2004), but these results await further confirmation through additional studies in large, heterogeneous basins.

Acknowledgments Funding for this study was provided by the USGS National Water Quality Assessment Program. The authors thank Martyn Smith for GIS support. Thanks also to James Shanley and four anonymous reviewers for their constructive comments on an earlier version of this manuscript.

Open Access This article is distributed under the terms of the Creative Commons Attribution License which permits any use, distribution, and reproduction in any medium, provided the original author(s) and the source are credited.

\section{References}

Ågren A, Buffam I, Berggren M, Bishop K, Jansson M, Laudon $\mathrm{H}$ (2008) Dissolved organic carbon characteristics in boreal streams in a forest-wetland gradient during the transition between winter and summer. J Geophys Res 113:G03031. doi:10.1029/2007JG000674

Aiken GR, McKnight DM, Thorn KA, Thurman EM (1992) Isolation of hydrophilic acids from water using macroporous resins. Org Geochem 18:567-573

Aiken GR, Gilmour CC, Krabbenhoft DP, Orem W (2011) Dissolved organic matter in the Florida Everglades: implications for ecosystem restoration. Crit Rev Environ Sci Technol 41:217-248

Benoit JM, Mason RP, Gilmour CC, Aiken GR (2001) Constants for mercury binding by dissolved organic matter isolates from the Florida Everglades. Geochim Cosmochim Acta 65:4445-4451

Beven KJ, Kirkby MJ (1979) A physically based, variable contributing area model of basin hydrology. Hydrol Sci Bull 24:43-69

Boyer EW, Hornberger GM, Bencala KE, McKnight DM (1997) Response characteristics of DOC flushing in an alpine catchment. Hydrol Proc 11:1635-1647
Bradley PM, Burns DA, Riva-Murray K, Brigham ME, Button DT, Chasar LC, Marvin-DiPasquale M, Lowery MA, Journey CA (2011) Spatial and seasonal variability of methylmercury in two stream basins in the eastern United States. Environ Sci Technol 45:2048-2055

Brigham ME, Wentz DA, Aiken GR, Krabbenhoft DP (2009) Mercury cycling in stream ecosystems. 1. Water column chemistry and transport. Environ Sci Technol 43:2720-2725

Burns DA, Riva-Murray K, Bradley PM, Aiken GR, Brigham ME (2012) Landscape controls on total and methyl Hg in the upper Hudson River basin, New York, USA. J Geophys Res 117:G01034. doi:10.1029/2011JG001812

Bushey JT, Driscoll CT, Mitchell MJ, Selvendiran P, Monteseoca MR (2008) Mercury transport in response to storm events from a northern forest landscape. Hydrol Proc 22:4813-4826

Chiarenzelli JR, McLelland JM (1993) Granulite facies metamorphism palaeo-isotherms and disturbance of the $\mathrm{U}-\mathrm{Pb}$ systematic of zircon in anorogenic plutonic rocks from the Adirondack Highlands. J Metamorph Geol 11:59-70

Cimmery V (2007) User guide for SAGA [version 2.0]. http:// www.saga-gis.org/en/index.html. Accessed 30 Jan 2012

Dahl TE, Dick J, Swords J, Wilen BO (2009) Data collection requirements and procedures for mapping wetland, deepwater and related habitats of the United States. Division of Habitat and Resource Conservation, National Standards and Support Team, Madison

Dennis IF, Clair TA, Driscoll CT, Kamman N, Chalmers A, Shanley J, Norton SA, Kahl S (2005) Distribution patterns of mercury in lakes and rivers of northeastern North America. Ecotoxicology 14:113-123

Dittman JA, Shanley JB, Driscoll CT, Aiken GR, Chalmers AT, Towse JE (2009) Ultraviolet absorbance as a proxy for total dissolved mercury in streams. Environ Pollut 157:19531956

Dittman JA, Shanley JB, Driscoll CT, Aiken GR, Chalmers AT, Towse JE, Selvendiran P (2010) Mercury dynamics in relation to dissolved organic carbon concentration and quality during high flow events in three northeastern U.S. streams. Water Resour Res 46:W07522. doi:10.1029/2009 WR008351

Driscoll CT, Blette V, Yan C, Schofield CL, Munson R, Holsapple J (1995) The role of dissolved organic carbon in the chemistry and bioavailability of mercury in remote Adirondack lakes. Water Air Soil Pollut 80:499-508

Driscoll CT, Holsapple J, Schofield CL, Munson R (1998) The chemistry and transport of mercury in a small wetland in the Adirondack region of New York, USA. Biogeochemistry 40:137-146

Eklöf K, Fölster J, Sonesten L, Bishop K (2012) Spatial and temporal variation of $\mathrm{THg}$ concentrations in run-off water from 19 boreal catchments, 2000-2010. Environ Pollut 164:102-109

Evers DC, Han Y-J, Driscoll CT, Kamman NC, Goodale MW, Lambert KF, Holsen TM, Chen CY, Clair TA, Butler T (2007) Biological mercury hot spots in the northeastern United States and southeastern Canada. BioScience 57: $29-43$

Gerbig CA, Kim CS, Stegemeier JP, Ryan JN, Aiken GR (2011) Formation of nanocolloidal metacinnabar in mercuryDOM-sulfide systems. Environ Sci Technol 45:9180-9187 
Gerbig CA, Ryan JN, Aiken GR (2012) The effects of dissolved organic matter on mercury biogeochemistry. In: Liu G, Cai Y, O’Driscoll NO (eds) Environmental chemistry and toxicology of mercury. Wiley, New York, pp 259-292

Grigal DF (2002) Inputs and outputs of mercury from terrestrial watersheds: a review. Environ Rev 10:1-39

Grigal DF (2003) Mercury sequestration in forest and soils: a review. J Environ Qual 32:393-405

Haitzer M, Aiken GR, Ryan JN (2002) Binding of mercury(II) to dissolved organic matter: the role of the mercury-to-DOM concentration ratio. Environ Sci Technol 36:3564-3570

Hall BD, Aiken GR, Krabbenhoft DP, Marvin-DiPasquale M, Swarzenski CM (2008) Wetlands as principal zones of methylmercury production in southern Louisiana and the Gulf of Mexico region. Environ Pollut 154:124-134

Hinton MJ, Schiff SL, English MC (1997) The significance of storms for the concentration and export of dissolved organic carbon from two Precambrian catchments. Biogeochemistry 36:67-88

Hood E, Williams MW, McKnight DM (2005) Sources of dissolved organic matter (DOM) in a Rocky Mountain stream using chemical fractionation and stable isotopes. Biogeochemistry 74:231-255

Hood E, Gooseff MN, Johnson SL (2006) Changes in the character of stream water dissolved organic carbon during flushing in three small watersheds, Oregon. J Geophys Res 111:GO1007. doi:10.1029/2005IG000082

Hurley JP, Benoit JM, Babiarz CL, Shafer MM, Andren AW, Sullivan JR, Hammond R, Webb DA (1995) Influences of watershed characteristics on Wisconsin rivers. Environ Sci Technol 29:1867-1875

Jenkins J, Roy K, Driscoll C, Buerkett C (2005) Acid rain and the Adirondacks: a research summary. Adirondack Lakes Survey Corp, Raybrook

LaPoint SD, Curren RP, Halasz SS, Barge JW, Spada DM, Karasin LN (2004) Wetlands effects database and GIS for the Adirondack Park. New York State Adirondack Park Agency, Ray Brook

Leenheer JA, Croué J-P (2003) Characterizing aquatic organic matter. Environ Sci Technol 37:18A-26A

Lehner B, Döll P (2004) Development and validation of a global database of lakes, reservoirs and wetlands. J Hydrol 296: $1-22$

Lewis ME, Brigham ME (2004) Low level mercury. U.S. Geological Survey Techniques of Water-Resources Investigations, Book 9, chap A5, Section 5.6.4.B. http://water.usgs. gov/owq/FieldManual/chapter5/pdf/5.6.4.B_v1.0.pdf. Accessed 30 Jan 2012

Lindberg SE, Harriss RC (1974) Mercury-organic matter associations in estuarine sediments and interstitial water. Environ Sci Technol 8:459-462

Mierle G, Ingram R (1991) The role of humic substances in the mobilization of mercury from watersheds. Water Air Soil Pollut 56:349-357

Minor E, Stephens B (2008) Dissolved organic matter characteristics within the Lake Superior watershed. Org Geochem 39:1489-1501

Mulholland PJ (2003) Large-scale patterns in dissolved organic carbon concentration, flux, and sources. In: Findlay S, Sinsabaugh R (eds) Aquatic ecosystems: interactivity of dissolved organic matter. Elsevier, New York, pp 139-159
Natural Resources Conservation Service (NRCS) (2006) Soil survey of Hamilton County, New York. US Department of Agriculture, Natural Resources Conservation Service, Washington

Natural Resources Conservation Service (NRCS) (2010) Soil survey of Essex County, New York. US Department of Agriculture, Natural Resources Conservation Service, Washington

O'Brien RM (2007) A caution regarding rules of thumb for variance inflation factors, quality and quantity. Qual Quant 41:673-690

Olson ML, DeWild JF (1999) Techniques for the collection and species-specific analysis of low levels of mercury in water, sediment, and biota. US Geological Survey, WaterResources Investigations Report 99-4018-B, Middleton

Olson DM et al (2001) Terrestrial ecoregions of the world: a new map of life on earth. BioScience 51:933-938

Ravichandran M (2004) Interactions between mercury and dissolved organic matter-a review. Chemosphere 55: 319-331

Ravichandran M, Aiken GR, Ryan JN, Reddy MM (1999) Inhibition of precipitation and aggregation of metacinnabar (mercuric sulfide) by dissolved organic matter isolated from the Florida Everglades. Environ Sci Technol 33: $1418-1423$

Rantz SE et al (1982) Measurement and computation of streamflow, vol 1, Measurement of stage and discharge. US Geological Survey Water Supply Paper 2175, Reston

Riscassi AL, Scanlon TM (2011) Controls on stream water dissolved mercury in three mid-Appalachian forested headwater catchments. Water Resour Res 47:W12512. doi: 10.1029/2011WR010977

Rostan JC, Cellot B (1995) On the use of UV spectrophotometry to assess dissolved organic carbon variations in the upper Rhone River. Aquat Sci 57:70-80

Schelker J, Burns DA, Weiler M, Laudon H (2011) Hydrological mobilization of mercury and dissolved organic carbon in a snow-dominated forested watershed: conceptualization and modeling. J Geophys Res 116:G01002. doi: 10.1029/2010JG001330

Schiff S, Aravena R, Melwhinney E, Elgood R, Warner B, Dillon P, Trumbore S (1998) Precambrian shield wetlands: hydrologic control of the sources and export of dissolved organic carbon. Clim Change 40:167-188

Schuster PF, Shanley JB, Marvin-Dipasquale M, Reddy MM, Aiken GR, Roth DA, Taylor HE, Krabbenhoft DP, DeWild JF (2008) Mercury and organic carbon dynamics during runoff episodes from a northeastern USA watershed. Water Air Soil Pollut 187:89-108

Selvendiran P, Driscoll CT, Bushey JT, Montesdeoca MR (2008) Wetland influence on mercury fate and transport in a temperate watershed. Environ Pollut 154:46-55

Selvendiran P, Driscoll CT, Montesdeoca MR, Choi H-D, Holsen TR (2009) Mercury dynamics and transport in two Adirondack lakes. Limnol Oceanogr 54:413-427

Shanley JB, Kamman NC, Clair TA, Chalmers A (2005) Physical controls on total and methylmercury in streams and lakes of the northeastern USA. Ecotoxicology 14:125-134

Shanley JB et al (2008) Comparison of total mercury and methylmercury cycling at five sites using the small watershed approach. Environ Pollut 154:143-154 
Skyllberg U (2008) Competition among thiols and inorganic sulfides and polysulfides for $\mathrm{Hg}$ and $\mathrm{MeHg}$ in wetland soils and sediments under suboxic conditions: illumination of controversies and implications for $\mathrm{MeHg}$ net production. J Geophys Res 113:G00C03. doi:10.1029/2008JG000745

Spencer RGM, Aiken GR, Dyda RY, Butler KD, Bergamaschi BA, Hernes PJ (2010) Comparison of XAD with other dissolved lignin isolation techniques and a compilation of analytical improvements for the analysis of lignin in aquatic settings. Org Geochem 41:445-453

Tsui MTK, Finlay JC (2011) Influence of dissolved organic carbon on methylmercury bioavailability across Minnesota stream ecosystems. Environ Sci Technol 45:5981-5987

US EPA (Environmental Protection Agency) (1996) Method 1669, Sampling ambient water for trace metals at EPA water quality criteria levels, Washington
Vidon PGF, Hill AR (2004) Landscape controls on the hydrology of stream riparian zones. J Hydrol 292:210-228

Weishaar JL, Aiken GR, Bergamschi BR, Fram MS, Fujii R, Mopper K (2003) Evaluation of specific ultraviolet absorbance as an indicator of the chemical composition and reactivity of dissolved organic carbon. Environ Sci Technol 37:4702-4708

Yin X, Balogh SJ (2002) Mercury concentrations in stream and river water: an analytical framework applied to Minnesota and Wisconsin. Water Air Soil Pollut 138:79-100

Zumstein J, Buffle J (1989) Circulation of pedogenic and aquagenic carbon in an eutrophic lake. Water Res 23: 229-239 